\title{
Listening on display
}

Citation for published version (APA):

Semmerling, L. (2020). Listening on display: exhibiting sounding artworks 1960s-now. [Doctoral Thesis, Maastricht University]. Maastricht University. https://doi.org/10.26481/dis.20200430ls

Document status and date:

Published: 01/01/2020

DOI:

10.26481/dis.20200430ls

Document Version:

Publisher's PDF, also known as Version of record

\section{Please check the document version of this publication:}

- A submitted manuscript is the version of the article upon submission and before peer-review. There can be important differences between the submitted version and the official published version of record.

People interested in the research are advised to contact the author for the final version of the publication, or visit the DOI to the publisher's website.

- The final author version and the galley proof are versions of the publication after peer review.

- The final published version features the final layout of the paper including the volume, issue and page numbers.

Link to publication

\footnotetext{
General rights rights.

- You may freely distribute the URL identifying the publication in the public portal. please follow below link for the End User Agreement:

www.umlib.nl/taverne-license

Take down policy

If you believe that this document breaches copyright please contact us at:

repository@maastrichtuniversity.nl

providing details and we will investigate your claim.
}

Copyright and moral rights for the publications made accessible in the public portal are retained by the authors and/or other copyright owners and it is a condition of accessing publications that users recognise and abide by the legal requirements associated with these

- Users may download and print one copy of any publication from the public portal for the purpose of private study or research.

- You may not further distribute the material or use it for any profit-making activity or commercial gain

If the publication is distributed under the terms of Article $25 \mathrm{fa}$ of the Dutch Copyright Act, indicated by the "Taverne" license above, 
In 2012, ZKM | Center for Art and Media Karlsruhe put on the largescale group show Sound Art: Sound as a Medium of Art. One of the works on display was German artist Rolf Julius' Backstage from 2008, an installation that seeks to recreate the situation on the floor of the artist's studio with stones, vessels, paint pigments and loudspeaker cones strewn about a wooden pedestal. The many small and fragile parts confronted curators and conservators with the challenge to keep visitors at a distance. When a thick rope seemed to have too big an impact on the delicate visual aesthetics of the work, they decided to work with a light beam alarm system instead. As soon as a visitor crossed the thin beam of light in front of the work, an alarm would sound. While this sound effectively warns the visitors of quiet painting exhibitions to step back from the work, it did not fulfil that same function in the noisy gallery spaces of the media art museum. Here visitors readily interpreted the high beeping sound as a part of the work and started to play with the alarm as if it belonged to an interactive art installation. Instead of listening intently to the quiet sounds of the artwork, visitors enthusiastically bent over the installation and into the alarm system to trigger the sound.

This anecdote, shared by a conservator in passing, inspired me to investigate at a larger scale how sounding artworks have challenged and continue to challenge established curatorial strategies for the making of exhibitions. With an ear to developing new curatorial strategies, this dissertation attempts to unravel these challenges by inquiring how visitors have experienced and evaluated sounding artworks in exhibitions, how curators have dealt with artists' conceptions of sound, the everyday reality of the institution, and the technologies available, and what aesthetic-experiential and technological challenges artists felt faced with when positioning their sounding artworks in exhibitions. As they are usually not the only ones to make these exhibitions happen, my research also involves their support staff, including artist assistants, advising engineers and museum technical staff.

Focusing on the countries with the most elaborate institutional exhibition histories of sounding artworks, I have selected a total of 23 exhibitions that took place in Germany and the US since the 1960s as case studies. As I was interested to explore the range of challenges that occurred in different institutional environments, I made sure to select solo and group exhibitions that took place at a broad variety of venues, which could all be described as hubs in the sense that they showed a considerable dedication to presenting sounding artworks. To me, such sounding artworks could be any sculptures and installations that are meant to openly resound throughout an exhibition space, so they transcend art historical distinctions between movements or genres like Fluxus, sound art, or Klangkunst. To learn about the selected exhibitions, I set out to conduct research in the 
exhibition files of the institutional archives, interview artists, curators and their support staff, and observe and interview visitors right inside an exhibition that took place while I was conducting my research. These activities intersected when the materials I found in the archives helped to elicit memories from curators and artists during interviews, or when they allowed me to observe visitors from the past whose interactions with artworks have been captured in exhibition documentations. Inspired by Martin Forsey's plea for a mixed-methods ethnography (2010), these intersections led me to think of my activities as bound together by my "engaged listening". This engaged listening was not directed at the sounding artworks, but at the visitors who left traces in the institutional archives as well as at the visitors I interviewed and observed in the exhibition. I listened figuratively to the curators, artists, and technicians whose struggles with sounding artworks have been documented in the archives, and I literally listened to the curators, artists and technicians who met with me to discuss their experiences with exhibiting sounding artworks. I have then analyzed my fieldnotes, interview transcripts and archival materials by drawing on three theoretical concepts, each of which focuses on a specific dimension of the exhibition.

The third chapter focuses on the exhibition as a social ritual, and it investigates how visitors as well as curators and artists have perceived sounding artworks to impact this ritual. While some visitors, curators, and artists have claimed that specific sounding artworks effectively slowed and quieted down visitors on their route through an exhibition, others have pointed out that the exhibition conditions had a quietening and decelerating effect on them, or that they should have brought about that effect. I have learned about the possibility of these kinds of effects through Dorotha von Hantelmann's manual of How to Do Things with Art, which transfers the linguistic notion of performativity into the realm of the visual arts to argue that artworks can impact society by intervening in exhibition conventions. Assuming that these exhibition conventions are closely intertwined with broader socio-economic developments, von Hantelmann suggests that artworks which create meaningful interventions in their exhibition settings also interfere with larger societal conventions. In the third chapter, I am developing her art theoretical approach to analyzing how artists inscribe performative effects into artworks into an empirical approach to investigating how visitors, curators, and also artists ascribe performative effects to sounding artworks in exhibitions. This approach draws on exhibition studies scholarship when it analyzes how artworks relate to their exhibition environments, but it also moves away from exhibition studies when it replaces the art theoretical subject of the implied viewer with an empirically constituted notion of the visitor. While these visitors still ascribe some performative effects to artworks, they appear to be equally sensitive to the influence that the institutional context may have on their perception of the artwork. Another performative effect that these visitors evoked was the feeling that the sounds of the artworks activated 
them to become more involved either by directly engaging in the production of the sound, or by indirectly defining their listening position with respect to the sound. Here it became particularly clear that visitors, curators and artists do not necessarily ascribe the same performative effects to the same artworks as the visitors were often eager to get involved in ways that the curators and artists had not intended. While visitors' accounts of quiet introspection and active involvement have a tendency to evoke the visiting ideals of individual contemplation and sociable entertainment, which have often been conceptualized as mutually exclusive in the museum studies literature, they actually seemed to reinforce one another in the visitors' descriptions of the atmosphere of sociable contemplation that they found to prevail in several exhibitions with sounding artworks. Only curators who know about these visitor experiences can really work with them.

The fourth chapter of this dissertation centers around the perspectives of these curators to find out about the challenges they encountered as the sensory regime of the exhibition was overturned by sounding artworks. Just like the third chapter investigated the exhibition as a social ritual, the fourth chapter focuses on the sensory regimes that govern exhibition making and visiting. Drawing on sociologist Pierre Bourdieu's notion of the habitus, I could argue that curators define their curatorial strategies at the intersection of their sensory dispositions, i.e. their personal listening histories, and their institutional positions and ambitions (2013 [1972]). This dynamic applied to the attempts that institutional curators made to reform exhibition conventions, to the attempts that independent curators made to break with exhibition conventions, and especially to the attempts that artists and curators who founded their own institutions made to build new exhibition conventions. Many curators have emphasized the influence that artists have taken on their sensory dispositions, and I quickly noticed that their involvement with certain sensory repertoires like Fluxus or Klangkunst had a considerable impact on their approaches to showing sounding artworks. This was most apparent among the curators who had designed their own institutions dedicated to a specific sensory repertoire, but it featured in all the curatorial strategies that I have encountered. Building on Carrie Noland's critique of Bourdieu's habitus (2009), I have thus come to think of any exhibition as a rehearsal of sensory repertoires. This idea of the rehearsal is characterized by a constant back and forth between processes of cultural conditioning through repetition and moments of individual expression through improvisation. Any exhibition thus provides an opportunity for artists, curators, and visitors to come together to try to calibrate listening histories and synchronize institutional conventions to create listening experiences that are meaningful to some and hopefully many members of an artistic community and the people beyond that community as well. While Bourdieu's habitus thus persists as a structuring structure, it takes on a new dynamic when the focus shifts from economic wealth and academic degrees to ongoing communal rehearsals of sensory repertoires. 
Chapter five goes on to examine how artists and their support staff deal with the exhibition as a taskscape. The notion of the taskscape has been coined by the anthropologist Tim Ingold to describe how environments are constituted by and in turn constitutive of the activities of the people who inhabit them. The taskscape thus allowed me to shed light on the material-organizational practices that are going on inside exhibitions. Ingold describes these processes to be shaped by an 'education of attention' that is quite similar to the rehearsal process outlined above when novices are supposed to learn from experienced practitioners through a process of imitation and improvisation. The challenge with exhibition taskscapes, however, is that artists tend to present their works in many different institutional environments. Analyzing the organizational and material affordances that these artists and their support staff have recognized in those institutional environments, I could identify two sets of tasks that most practitioners had to deal with. One set of tasks was concerned with the timing of the sounds in the exhibition, so loops had to be guarded and sounds had to be activated, and the other set of tasks was concerned with the placement of the sounds in the exhibition, so galleries had to be soundproofed and works had to be tuned to the acoustics of these galleries. When comparing the ways in which artists, curators and their support staff approached these tasks in different institutional environments, it quickly became apparent that the taskscape was more clearly laid out at institutions with a certain dedication to a specific sensory repertoire and less clearly defined at institutions that are not involved with any specific sensory repertoire. In an institution that is not dedicated to a specific sensory repertoire, artists and curators do thus not necessarily agree on the definition, the distribution and the delivery of tasks like the soundproofing of the gallery and the tuning of the speakers. In a situation where artistic practices constantly move across different institutional conventions, taskscapes are thus no longer a matter of educating attention, but of negotiating attention.

This would mean that the often-lamented challenge of soundbleed in group exhibitions is not really a fundamental problem of sound in exhibitions, it only becomes a problem in exhibitions that engage conflicting sensory repertoires or those specific sensory repertoires that require isolation. Throughout the argument of the book, the question about the challenges of exhibiting sounding artworks thus evolves from a challenge connected to the intrinsic nature of sound to a challenge of aligning the ideas and ideals that practitioners have about the ways in which sound should be attended to in exhibitions. This allows me to draw important lessons for the research and development of new curatorial strategies, which are encouraged to leave the ideal of doing justice to an artwork behind and instead facilitate a rehearsal of the sensory repertoires from which the artwork has grown and remain attentive to the exhibition taskscape that is implied in those specific sensory repertoires. 